\title{
Enhanced Liver Uptake of Opsonized Red Blood Cells After In Vivo Transfer of FerRIIA cDNA to the Liver
}

\author{
By Petr Bezdicek, Stefan Worgall, Imre Kovesdi, Moo-Kyung Kim, J ong-Gu Park, Theresa Vincent, \\ Philip L. Leopold, Alan D. Schreiber, and Ronald G. Crystal
}

\begin{abstract}
Fc $\gamma$ receptors convey to phagocytic cells the ability to recognize, bind, and intemalize IgG-coated cells and microorganisms. The present study demonstrates the use of adenovirus (Ad)-mediated gene transfer of human Fc $\gamma$ receptor IIA cDNA to convert normally nonphagocytic cells (hepatocytes) into functional equivalents of phagocytic cells. Ad vector in vitro transfer and expression of FC $\gamma$ RIIA cDNA in primary rat hepatocytes was confirmed by flow cytometry anti-Fc $\gamma$ RIIA immunodetection, and the function of the receptor was demonstrated by enhanced binding and phagocytosis of ${ }^{51} \mathrm{Cr}$-labeled IgG-opsonized erythrocytes. After in vivo gene transfer to rats, expression of FC $\gamma$ RIIA CDNA in hepatocytes was confimed by Northem analysis and immunohistochem-
\end{abstract}

$\mathbf{P}$

HAGOCYTOSIS OF IgG-coated cells and microorganisms, an important component of host defense, is mediated by receptors for the $\mathrm{Fc}$ portion of $\mathrm{IgG}$ ( $\mathrm{Fc} \gamma$ receptors) expressed on monocytes/macrophages and neutrophils. ${ }^{1-4}$ The 3 classes of Fc $\gamma$ receptors (Fc $\gamma$ RI, Fc $\gamma$ RII, and Fc $\gamma$ RIII) differ by size, structure, ligand binding specificity, and cellular distribution. ${ }^{1-3}$ The importance of Fc $\gamma$ receptors in host defense is highlighted by disorders such as systemic lupus erythematosus and chronic renal and liver failure, in which enhanced susceptibility to infection is associated with a downregulation of $\mathrm{Fc} \gamma$ receptors. ${ }^{5-7}$ Likewise, when there is a deficiency in the number and/or function of mononuclear and/or polymononuclear phagocytes, such as occurs in association with chemotherapy and prolonged administration of corticosteroids, the adaptive immune system cannot effectively use IgG opsonization as a strategy to aid in host defense..$^{8-11}$

Based on these concepts, we hypothesized that in vivo clearance of IgG-coated cells might be enhanced by inducing Fc $y$ receptor expression in normally nonphagocytic cells in the liver, an organ that normally plays a major role in the clearance

From the Division of Pulmonary and Critical Care Medicine, Weill Medical College of Cornell University, New York, NY; GenVec, Inc, Rockville, MD; InKine Pharmaceutical Co, Inc, Blue Bell, PA; and The University of Pennsylvania School of Medicine, Philadelphia, PA.

Submitted December 14, 1998; accepted July 10, 1999.

Supported in part by Grants No. P01 HL51746, P01 HL59312, and AI 22193 from the National Institutes of Health; the Cystic Fibrosis Foundation (Bethesda, MD); the Will Rogers Memorial Fund (White Plains, NY); GenVec, Inc (Rockville, MD); and InKine Pharmaceutical Co, Inc (Blue Bell, PA).

Address reprint requests to Ronald G. Crystal, MD, Division of Pulmonary and Critical Care Medicine, The New York Hospital-Cornell Medical Center, 520 E 70th St, ST 505, New York, NY 10021; e-mail: geneticmedicine@mail.med.cornell.edu.

The publication costs of this article were defrayed in part by page charge payment. This article must therefore be hereby marked "advertisement" in accordance with 18 U.S.C. section 1734 solely to indicate this fact.

(c) 1999 by The American Society of Hematology.

0006-4971/99/9410-0002\$3.00/0 istry. Rats infected with the Ad vector carrying the Fc $\gamma$ RIIA cDNA demonstrated enhanced clearance of opsonized erythrocytes, but not nonopsonized erythrocytes, from the circulation with increased sequestration within the liver. Together, these data demonstrate that Ad-mediated Fc $\gamma$ RIIA gene transfer can convert nomally IgG-nonphagocytic cells into phagocytic cells capable of recognizing, binding, and ingesting an opsonized particulate antigen, suggesting that gene transfer strategies might be used to transiently augment host defense by enhancing the clearance of immune complexes.

() 1999 by The American Society of Hematology.

of IgG-coated complexes. ${ }^{12-14}$ To evaluate this hypothesis, we used an adenovirus (Ad) gene transfer vector to express normal human Fc $\gamma$ RIIA, a Fc $\gamma$ RII allotype with affinity for $\operatorname{IgG2,2,15}$ cDNA in rat liver cells in vitro and in vivo, and evaluated the ability of the modified liver cells to phagocytize opsonized red blood cells. The in vitro data demonstrate that Fc $\gamma$ RIIA cDNA genetic modification of primary rat hepatocytes enhances the ability of these cells to bind and phagocytize IgG opsonized cells. The in vivo data demonstrate that Fc $\gamma$ RIIA cDNA transfer to hepatocytes enhances the clearance of $\mathrm{IgG}$ opsonized cells by the liver from the circulation.

\section{MATERIALS AND METHODS}

Adenovirus vectors. The replication-deficient recombinant Ad vectors AdCMVFc $\gamma$ RIIA and AdCMVNull are both E1a ${ }^{-}$, partial E1b ${ }^{-}$, partial E3 ${ }^{-}$vectors based on adenovirus type 5 (Ad5), in which an expression cassette containing a promoter driving the expression of a recombinant gene is inserted at the site of the E1 deletion. ${ }^{16,17}$ AdCMVFc $\gamma$ RIIA contains an expression cassette of the cytomegalovirus (CMV) early/intermediate promoter/enhancer followed by the human Fc $\gamma$ RIIA cDNA isoform H/R $131^{18}$ and a SV 40 stop/poly (A) signal. AdCMVNull is identical, except that it lacks the gene in the expression cassette. ${ }^{19}$ The Ad vectors were propagated, purified, and stored at $-70^{\circ} \mathrm{C}$, as previously described. ${ }^{16,17}$ Titers of viral preparations were determined by plaque assay using 293 cells. ${ }^{20}$ All preparations were free of replication competent Ad. ${ }^{21}$

Primary hepatocyte cultures. Primary hepatocyte cultures ${ }^{22}$ were established from 250 to $300 \mathrm{~g}$ female Sprague-Dawley rats (Taconic, Germantown, NY). Animals were anesthetized by intramuscular injection of ketamine $(60 \mathrm{mg} / \mathrm{kg}$; Fort Dodge Lab, Inc, Fort Dodge, IA) and xylazine $(5 \mathrm{mg} / \mathrm{kg}$; Butler Co, Columbus, $\mathrm{OH})$. The portal vein was cannulated and the liver was perfused and digested with collagenase solution (GIBCO BRL, Gaithersburg, MD). Hepatocytes were grown in 1:1 mixture of Dulbecco's Modified Eagle Medium (DMEM; Biofluids, Rockville, MD) and Waymouth Medium (Biofluids) containing dexamethasone (20 ng/mL; Sigma, St Louis, MO), insulin-transferrin-sodiumselenite media supplement $(1 \mu \mathrm{L} / \mathrm{mL} ;$ Sigma), and gentamicin (10 $\mu \mathrm{g} / \mathrm{mL}$; Sigma), penicillin G (50 U/mL; GIBCO BRL), and streptomycin $(50 \mu \mathrm{L} / \mathrm{mL}$; GIBCO BRL) on fibronectin (Sigma)-coated 6-well tissue culture plates (Becton Dickinson Labware, Franklin Lakes, NJ).

Expression and function of Fc $\gamma$ RIIA in primary rat hepatocytes. To assess expression of FcyRIIA by immunodetection flow cytometry 
analysis (EPICS XL; Coulter Corp, Miami, FL), primary rat hepatocyte cultures were infected with AdCMVFc $\gamma$ RIIA at multiplicity of infection (moi) 10, using noninfected cells and cells infected with AdCMVNull as controls. The cells were incubated with phosphate-buffered saline solution, pH 7.4 (PBS; Biofluids) containing $2 \%$ goat serum on ice for 30 minutes followed by mouse anti-Fc $\gamma$ RIIA monoclonal antibody IV.3 (20 $\mu \mathrm{g} / \mathrm{mL}$; Medarex, Annandale, NJ) for 30 minutes on ice. The cells were then washed in PBS, incubated with fluorescein isothiocyanate (FITC)-conjugated goat antimouse $\left[\mathrm{F}(\mathrm{ab})_{2}\right]$ fragments (Boehringer Mannheim, Indianapolis, IN) for 30 minutes, washed in PBS, and analyzed by flow cytometry. Isotype-matched mouse monoclonal antibodies (IgG2b; Sigma) were analyzed as negative controls.

The function of the Fc $\gamma$ RIIA protein expressed by the rat hepatocytes was assessed by quantifying binding and phagocytosis of Ig-opsonized ${ }^{51} \mathrm{Cr}$-labeled sheep red blood cells (SRBC) ${ }^{23}$ by the hepatocytes. Primary rat hepatocytes $\left(5 \times 10^{5} /\right.$ well $)$ were infected with AdCMVFc $\gamma$ RIIA (moi 10), using noninfected cells and cells infected with AdCMVNull as controls. After 48 hours, the hepatocytes were incubated for 60 minutes with $\mathrm{IgG}$ rabbit antisheep red blood cell antibody (Accurate Chemical \& Scientific Corp, Westbury, NY) -coated, ${ }^{51} \mathrm{Cr}$-labeled (DuPont NEN, Boston, MA) SRBC (Accurate). Nonopsonized ${ }^{51} \mathrm{Cr}$-labeled SRBC were used as controls. To evaluate the binding of IgG-opsonized ${ }^{51} \mathrm{Cr}$-SRBC to the Fc $\gamma$ RIIA cDNA-modified hepatocytes, the hepatocytes were washed 3 times in PBS and then lysed by incubation in $0.5 \%$ sodium dodecyl sulphate (SDS) solution (Sigma) for 10 minutes. To evaluate phagocytosis, hepatocytes were incubated with SRBC for 60 minutes, washed 3 times in PBS, incubated for 60 seconds in hypotonic SRBC lysing buffer $(31 \mathrm{mmol} / \mathrm{L}$ ammonia chloride, 2 $\mathrm{mmol} / \mathrm{L}$ potassium bicarbonate, $20 \mu \mathrm{mol} / \mathrm{L}$ ethylenediaminetetraacetic acid; all from Sigma) to lyse bound noninternalized SRBC, washed, and then lysed in $0.5 \%$ SDS for 10 minutes. To evaluate phagocytosis at different time points, hepatocytes were incubated with SRBC for 10, 30, and 60 minutes. The hepatocyte to SRBC ratio for all incubations was 1:500. The radioactivity of lysates was measured using a gammacounter.

Expression and function of FcyRIIA in vivo. To evaluate the expression of Fc $\gamma$ RIIA cDNA and the function of Fc $\gamma$ RIIA protein in vivo, female Sprague-Dawley rats ( 250 to $300 \mathrm{~g}$ ) were anesthetized by intramuscular injection of ketamine $(60 \mathrm{mg} / \mathrm{kg})$ and xylazine $(5 \mathrm{mg} / \mathrm{kg})$. Based on the knowledge that greater than $90 \%$ of an intravenously administered Ad goes to the liver, ${ }^{24,25}$ the Ad vectors (AdCMVFc $\gamma$ RIIA, AdCMVNull) were administered to the liver via the external jugular vein $\left(10^{9}\right.$ plaque-forming units [pfu] in $\left.100 \mu \mathrm{L} 0.9 \% \mathrm{NaCl}\right)$. Naive animals were used as controls.

Northern analysis was used to demonstrate in vivo Fc $\gamma$ RIIA transcripts in the liver. After 48 hours, animals were killed (pentobarbital overdose intraperitoneally), total RNA was extracted, and expression of Fc $\gamma$ RIIA mRNA was assessed by Northern analysis. Total RNA was extracted (RNA Extraction Kit; Clontech, Palo Alto, CA) and transferred (10 $\mu \mathrm{g} / \mathrm{lane})$ to nylon membranes after electrophoretic separation through a $1 \%$ agarose gel. The membranes were assessed using a human Fc $\gamma$ RIIA cDNA probe labeled with ${ }^{32} \mathrm{P}$-deoxycytidine triphosphate (dCTP; Random Primer Labeling Kit; Stratagene, La Jolla, CA) for 2 hours using standard methods. ${ }^{26}{ }^{32} \mathrm{P}$-labeled human $\gamma$-actin cDNA was used as a positive control. ${ }^{22}$ To analyze the expression and distribution of the Fc $\gamma$ RIIA in the liver, livers were harvested 48 hours after administration of AdFc $\gamma$ RIIA, AdNull or from uninfected animals. The organs were fixed with $4 \%$ paraformaldehyde for 24 hours and then transferred to $70 \%$ ethanol before embedding. Immunohistochemical staining for Fc $\gamma$ RIIA was performed on $5-\mu \mathrm{m}$, paraffin-embedded sections using the anti-FcyRII antibody IV.3. An isotype (IgG2b) -matched antibody was used as a control. The antibodies were incubated for 16 hours at $4{ }^{\circ} \mathrm{C}$ and then washed and incubated with biotinylated rabbit antimouse $\left[\mathrm{F}\left(\mathrm{ab}^{\prime}\right)_{2}\right]$ (Boehringer Mannheim) for 30 minutes, followed by streptavidin-FITC (Boehringer Mannheim) for 30 minutes.
A rabbit anti-FITC alkaline phosphatase-labeled antibody (Boehringer Mannheim) was then incubated for 30 minutes, followed by detection with 4-nitro blue tetrazolium chloride (NBT)-5-bromo-4-chloro-3indoyl-phosphate (BCIP) substrate (Boehringer Mannheim). The samples were counterstained with nuclear fast red (DIGENE, Beltsville, MD) and analyzed by light microscopy.

To determine if in vivo transfer of the FcyRIIA to the liver was associated with enhanced clearance of $\operatorname{IgG}$ opsonized RBC from the circulation, rats were anesthetized and Ad vectors were administered as described above. Forty-eight hours later, ${ }^{51} \mathrm{Cr}$-labeled rat red blood cells (RRBC) were opsonized with IgG rabbit anti-RRBC antibodies (Accurate). The IgG-coated, ${ }^{51} \mathrm{Cr}$-labeled $\mathrm{RRBC}$ were administered intravenously via the femoral vein $\left(3.4 \times 10^{8} \mathrm{RRBC}\right.$ in $\left.500 \mu \mathrm{L} 0.9 \% \mathrm{NaCl}\right)$. Nonopsonized ${ }^{51} \mathrm{Cr}$-labeled RRBC were used as controls. At 5, 15, 30, 60, 90, and 120 minutes after injection of the ${ }^{51} \mathrm{Cr}$-labeled RRBC, blood samples were collected $(100 \mu \mathrm{L})$ from the external jugular vein and radioactivity of the samples was measured using a gamma counter. Clearance of RBC from the circulation was expressed as a percentage of RBC survival in the peripheral blood. ${ }^{27}$ The value obtained at 5 minutes after injection was considered $100 \%$. Animals were killed after 120 minutes by pentobarbital overdose.

To determine the uptake of the IgG-opsonized ${ }^{51} \mathrm{Cr}$-labeled RRBC in different organs, rats were infected with Ad vectors, and then opsonized and nonopsonized RRBC were administered as described above. Animals were killed 120 minutes after administration of the RRBC. Liver, lung, and spleen were removed, weighed, and homogenized in 20 $\mathrm{mL}$ of $\mathrm{H}_{2} \mathrm{O}$. Total radioactivity of the organ (dpm) was determined using

\section{anti-Fc $\gamma$ RIIA Isotype control}

\section{A. Control}
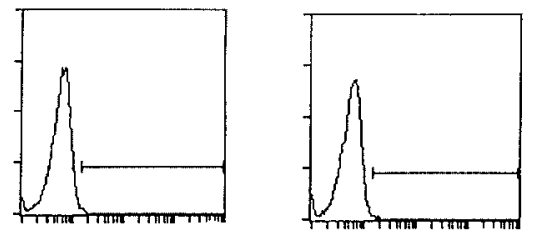

B. AdNull
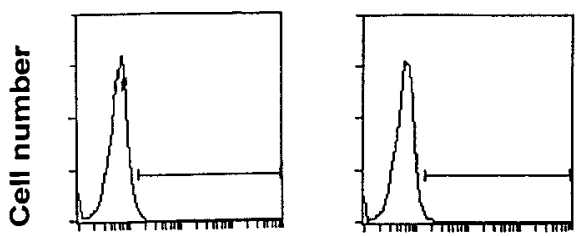

\section{AdFc $\gamma$ RIIA}
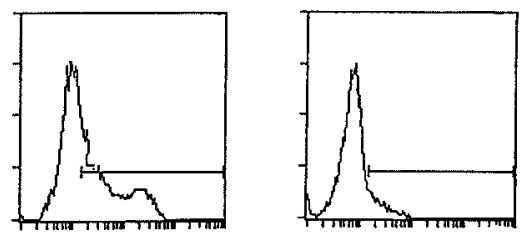

Relative light units

Fig 1. Expression of Fc $\gamma$ RIIA on the surface of primary rat hepatocyte cultures after Ad vector-mediated gene transfer of Fc $\gamma$ RIIA cDNA. Primary hepatocytes were infected with AdFc $\gamma$ RIIA and AdNull at $\mathbf{1 0}$ moi. After $\mathbf{4 8}$ hours, cells were incubated with anti-Fc $\gamma$ RIIA monoclonal antibody for $\mathbf{3 0}$ minutes, washed, and labeled with FITC-conjugated goat antimouse $\mathrm{F}\left(\mathrm{ab}^{\prime}\right)_{2}$ IgG for 30 minutes, washed, and fixed in $1 \%$ paraformaldehyde. Isotype-matched controls were used for all reactions. Shown is flow cytometry of (A) naive controls, (B) AdNull-infected cells, and (C) AdFc $\gamma$ RIIA-infected cells. 
a gamma-counter and expressed as a percentage of the total radioactivity injected intravenously.

To further analyze the uptake of $\operatorname{IgG}$ coated particles in vivo, fluorescent-labeled IgG-coated microspheres were injected intravenously in rats that had been infected with AdFcyRIIA or AdNull 48 hours previously. The fluorescent microspheres were prepared by mixing Sulfo-NHS-LC-Biotin (Pierce, Rockford, IL) with human IgG (Sigma) for 10 minutes at $4^{\circ} \mathrm{C}, \mathrm{pH} 8.0$, followed by the addition of glycine $(1 \mathrm{mg} / \mathrm{mL})$ to stop the reaction and dialysis in $10 \mathrm{mmol} / \mathrm{L}$ HEPES, $140 \mathrm{mmol} / \mathrm{L} \mathrm{KCl}, \mathrm{pH} 7.2$, for 2 hours to remove unbound biotin. The biotinylated IgG was then bound to $40 \mathrm{~nm}$ Neutr-Avidinlabeled red fluorescent microspheres (Molecular Probes, Eugene, OR). The number of microspheres injected was $6 \times 10^{12}$ particles/animal. One hour after the injection of the fluorescent-coated microspheres, the animals were killed and frozen sections of the livers were prepared by immediately freezing the tissue in TBS tissue freezing medium (Electron Microscopy Sciences, Fort Washington, PA). Frozen sections were fixed in $4 \%$ paraformaldehyde for 30 minutes and evaluated by fluorescence microscopy.

Statistical analysis. The results are expressed as the mean \pm standard error of the mean. Statistical comparisons were made using the unpaired 2-tailed Student's $t$-test.

\section{RESULTS}

AdFc $\gamma$ RIIA transfer to rat hepatocytes in vitro. To demonstrate the ability of an Ad vector expressing the AdFc $\gamma$ RIIA cDNA (AdFc $\gamma$ RIIA) to transfer and express human Fc $\gamma$ RIIA in vitro in rat hepatocytes, primary rat hepatocyte cultures were infected with AdFc $\gamma$ RIIA (moi, 10). Quantification of expression of FcyRIIA on the cell surface, determined by flow cytometry, demonstrated positive Fc $\gamma$ RIIA staining in $46 \%$ of cells after AdFc $\gamma$ RIIA infection (Fig 1). No expression of Fc $\gamma$ RIIA was demonstrated in noninfected or AdNull-infected primary rat hepatocytes. These results suggest that Ad-mediated Fc $\gamma$ RIIA cDNA transfer results in expression of the transgene in primary rat hepatocyte tissue cultures.

Function of Fc $\gamma$ RIIA transferred in vitro to rat hepatocytes. Function of the Fc $\gamma$ RIIA protein expressed on the primary rat hepatocytes after in vitro Ad-mediated gene transfer was assessed using a phagocytic assay using radiolabeled SRBC. Cells infected with AdFc $\gamma$ RIIA (moi, 10) showed increased binding of IgG-coated SRBC (Fig 2A; $P<.001$, for 30 and 60 minutes compared with values for noninfected and AdNullinfected cells) and phagocytosis of IgG-coated SRBC (Fig 2B; $P<.006$, for 30 and 60 minutes compared with values for noninfected and AdNull-infected cells). Increased binding and phagocytosis by hepatocytes expressing Fc $\gamma$ RIIA was observed after 10 minutes of incubation with opsonized erythrocytes with significant increase and plateau after 30 and 60 minutes. Noninfected and AdNull-infected rat hepatocytes showed a minimal amount of nonspecific binding and internalization of both nonopsonized and IgG-opsonized SRBC. These observa-

\section{A. Binding}

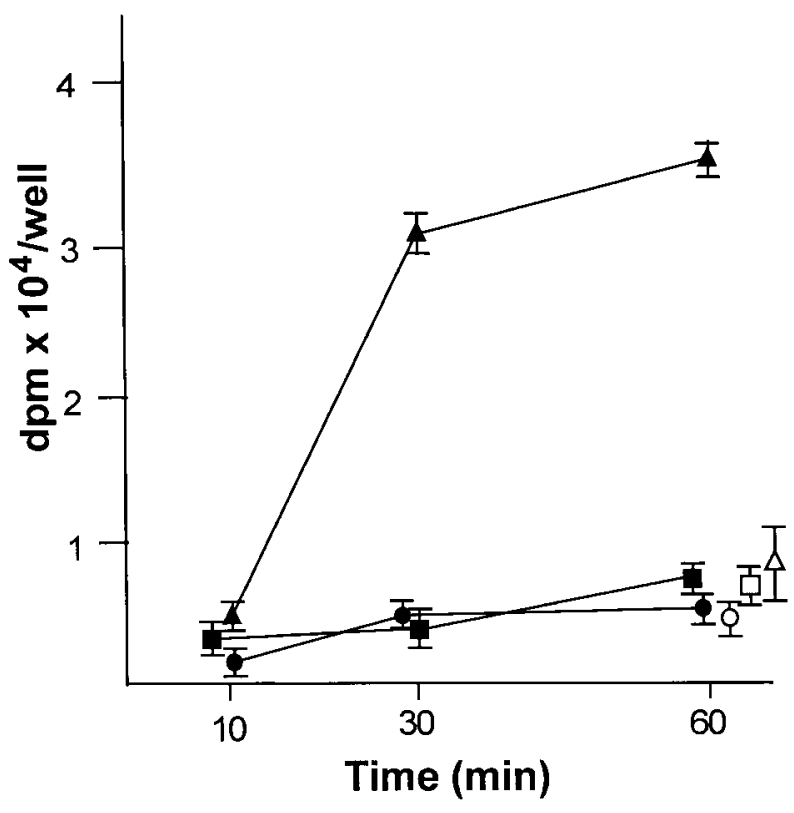

\section{B. Phagocytosis}

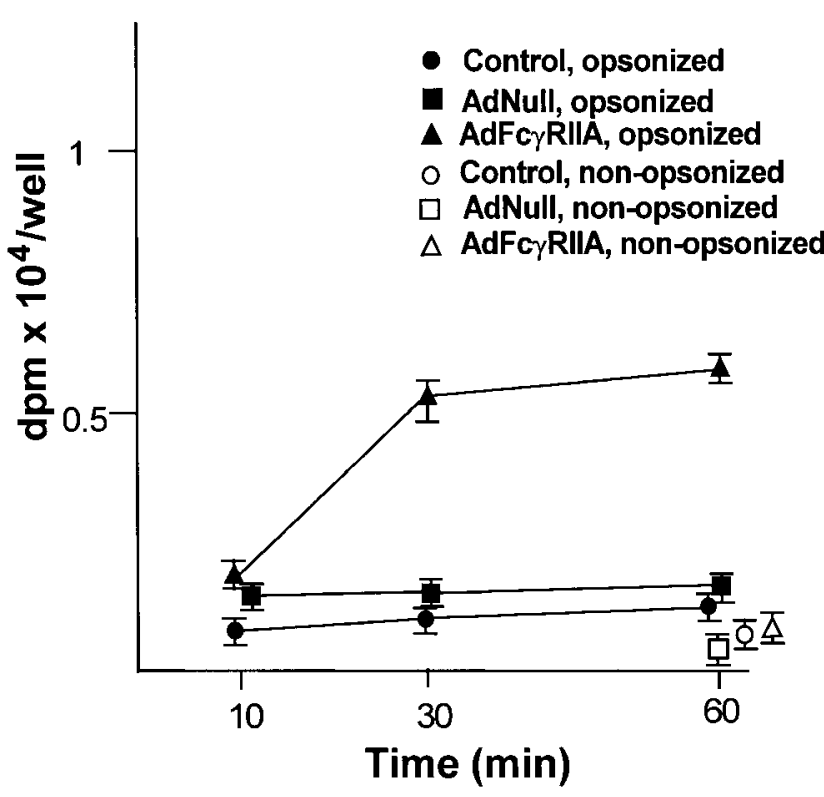

Fig 2. Binding and phagocytosis of opsonized SRBC by primary rat hepatocyte cultures at different time points after Ad-mediated Fc $\gamma$ RIIA cDNA gene transfer. Primary hepatocytes were infected with AdNull and AdFcyRIIA at 10 moi. After 48 hours, cells were incubated with IgG-coated ${ }^{51} \mathrm{Cr}$-labeled SRBC for 10, 30, and 60 minutes. As a control, the cells were incubated with nonopsonized SRBC for 60 minutes. To evaluate binding of IgG-coated SRBC to primary hepatocytes, cells were washed with PBS and then lysed by incubation with $0.5 \%$ SDS for 10 minutes. To evaluate SRBC phagocytosis by the primary hepatocytes, cells were washed with PBS and the SRBC bound to the cell surface were lysed by incubation with hypotonic lysis buffer for 1 minute. The cells were lysed by incubation with $0.5 \%$ SDS for 10 minutes and the radioactivity of lysate was quantified. (A) Binding of opsonized SRBC at 10, 30, and 60 minutes to hepatocytes that were not infected (control; 9 ), infected with AdNull $(\square)$, or infected with AdFc $\gamma$ RIIA ( $A$ ). Also indicated as controls are parallel cultures of cells incubated with nonopsonized SRBC for 60 minutes with uninfected hepatocytes $(\bigcirc)$, AdNull-infected hepatocytes ( $\square$ ), and AdFc $\gamma$ RIIA-infected hepatocytes ( $\triangle$ ). (B) Phagocytosis of opsonized RBC at 10, 30, and 60 minutes. The symbols are identical to that in (A). For all data, shown are the means of activity (dpm)/ well from 3 measurements \pm standard error. 

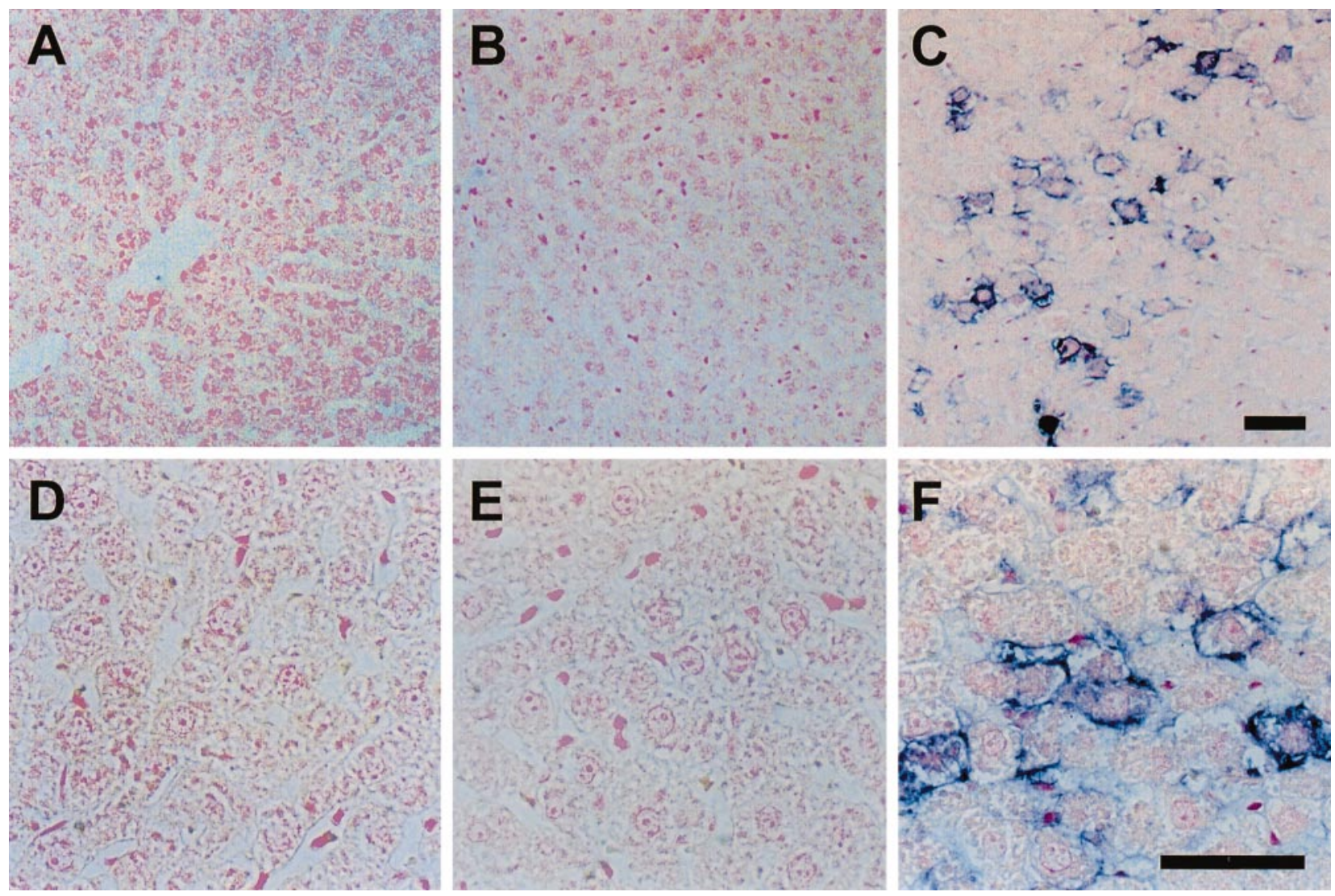

Fig 3. Expression of Fc $\gamma$ RIIA in rat liver in vivo after Ad-mediated Fc $\gamma$ RIIA cDNA gene transfer. Sprague Dawley rats received Ad Fc $\gamma$ RIIA or AdNull intravenously ( $\left.10^{\circ} \mathrm{pfu}\right)$. After $\mathbf{4 8}$ hours, the livers were removed and fixed, and paraffin-embedded sections were analyzed for Fc $\gamma \mathrm{RIIA}$ expression by immunohistochemistry using anti-Fc $\gamma$ RIIA antibody IV.3. (A and D) Naive control; (B and E) AdNull; (C and F) Ad Fc $\gamma$ RIIA-infected. (A, B, and C, bar $=50 \mu \mathrm{m} ; \mathrm{E}, \mathrm{D}$, and F [high power representative of A, B, and C], bar $=50 \mu \mathrm{m}$.)

tions provide evidence that Ad-mediated transfer of FcyRIIA cDNA results in expression of a functional phagocytic receptor on primary hepatocytes, enabling these cells to recognize, bind, and internalize opsonized particles.

AdFc rRIIA transfer to rat hepatocytes in vivo. To analyze if Fc $\gamma$ RIIA can be expressed in vivo in rat hepatocytes after intravenous administration of the AdFc $\gamma$ RIIA vector $\left(10^{9} \mathrm{pfu}\right)$, total RNA was extracted from rat liver and assessed by Northern analysis. This experiment demonstrated that intravenous administration of AdFc $\gamma$ RIIA resulted in expression of Fc $\gamma$ RIIA mRNA transcripts in the liver of the experimental animals. No FcyRIIA mRNA transcripts were observed in the liver of
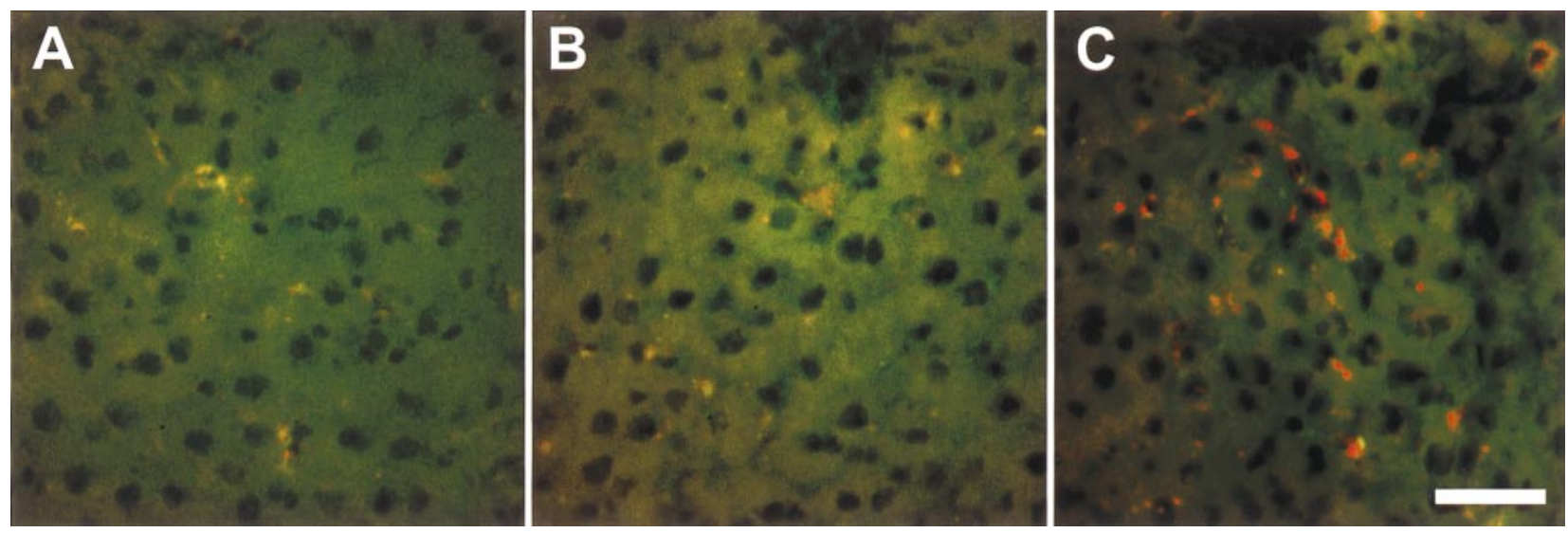

Fig 6. Localization of IgG fluorescent microspheres in vivo after Ad-mediated Fc $\gamma$ RIIA cDNA gene transfer. Sprague Dawley rats received Ad FcyRIIA or AdNull intravenously (109 pfu). After 48 hours, IgG fluorescent microspheres $\left(6 \times 10^{12}\right.$ particles) were injected intravenously, and 1 hour later the livers were removed and frozen section were prepared and analyzed by fluorescence microscopy. (A) Naive control; (B) AdNull-infected; and (C) Ad Fc $\gamma$ RIIA-infected. Bar $=50 \mu \mathrm{m}$. 
noninfected animals or animals infected with AdNull, although control $\gamma$-actin mRNA transcripts were similar in all samples (not shown). Analysis of liver sections of animals infected with Ad FcyRIIA or AdNull by immunohistochemistry showed positive staining for Fc $\gamma$ RIIA in liver parenchymal cells (hepatocytes) of the animals infected with Ad Fc $\gamma$ RIIA (Fig 3C and E), but not in control naive (Fig 3A and D) or AdNull-infected animals (Fig 3B and E). These observations confirm that in vivo Ad-mediated transfer of Fc $\gamma$ RIIA results in expression of the Fc $\gamma$ RIIA transgene in the liver.

AdFc $\gamma R I I A$ induced enhanced clearance of opsonized RBC in vivo. The function of Fc $\gamma$ RIIA expressed after intravenous administration of AdFc $\gamma$ RIIA ( $10^{9} \mathrm{pfu}$ ) was assessed by the clearance of radiolabeled IgG-opsonized and nonopsonized RRBC from the peripheral blood of experimental animals. Nonopsonized RRBC were not effectively cleared in noninfected animals or in AdNull and AdFc $\gamma$ RIIA-infected animals (Fig 4A; $P>$.2, all comparisons, all time points). In contrast, IgG-coated (opsonized) RRBC were rapidly cleared from the blood in the animals receiving AdFcyRIIA. One hour after administration of RRBC in noninfected animals, $54 \% \pm 3 \%$
RRBC remained in the blood compared with $33 \% \pm 4 \%$ in AdNull and 9\% $\pm 1 \%$ in FcyRIIA-infected animals (Fig 4B; $P<.001$, comparing values for Fc $\gamma$ RIIA-infected animals with AdNull and noninfected animals at all time points after intravenous injection of radiolabeled RRBC). Interestingly, infection with AdNull also increased clearance of IgG-coated RRBC compared with noninfected animals, but much less than that observed with AdFc $\gamma$ RIIA $(P<.01$, all comparisons).

To determine the uptake of RRBC in different organs (liver, lung, and spleen), animals were killed 120 minutes after administration of radiolabeled RRBC. No significant difference was observed in uptake of nonopsonized RRBC in noninfected and AdNull and AdFc $\gamma$ RIIA-infected animals (Fig 5A; $P>.3$, all comparisons). In contrast, AdFc $\gamma$ RIIA-infected animals showed significant increase in the liver uptake of IgG-coated RRBC $(69 \% \pm 6 \%)$ compared with AdNull infected $(41 \% \pm$ $4 \%)$ and noninfected animals $(27 \% \pm 2 \%$; Fig $5 \mathrm{~B} ; P<.04$, AdFc $\gamma$ RIIA-infected animals with AdNull and noninfected animals). An increased number of IgG-coated fluorescent microspheres was present in the liver sections of the animals infected with Ad FcyRIIA (Fig 6C) compared with naive

\section{A. Non-opsonized RBC}

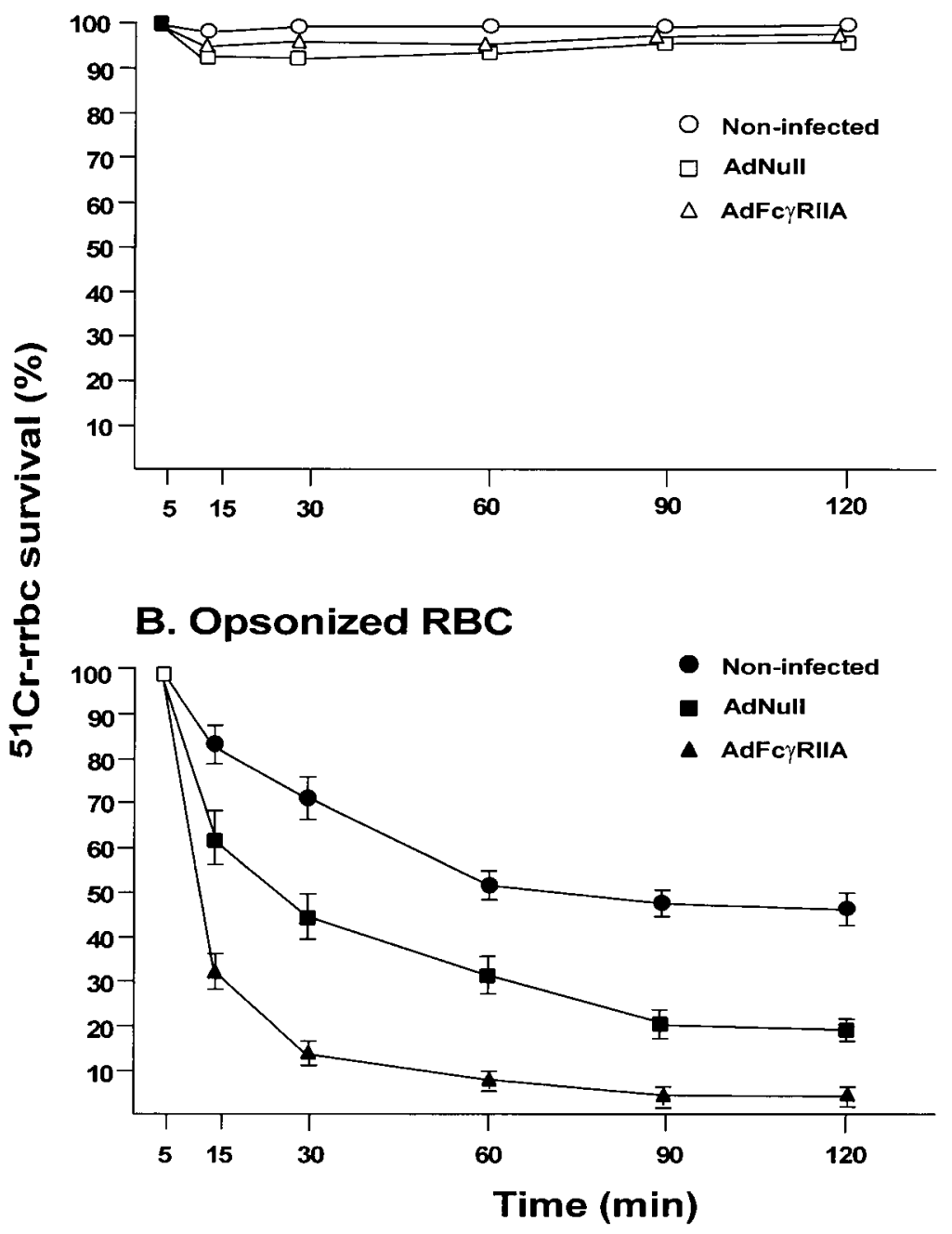

Fig 4. Clearance of ${ }^{51} \mathrm{Cr}$-labeled SRBC from the circulation after in vivo Ad-mediated FC $\gamma$ RIIA CDNA gene transfer. Sprague-Dawley rats were administered AdFc $\gamma$ RIIA or AdNull intravenously ( $\left.10^{\circ} \mathrm{pfu}\right)$. After 48 hours, ${ }^{51} \mathrm{Cr}$-labeled opsonized (IgG-coated) RRBC or nonopsonized RRBC as controls were injected intravenously. At $\mathbf{5}$ to $\mathbf{1 2 0}$ minutes, blood samples were collected and ${ }^{51} \mathrm{Cr}$-radioactivity measured using a gamma scintillation counter. The level of ${ }^{51} \mathrm{Cr}$-RRBC in the blood was expressed as a percentage of the value obtained at 5 minutes (100\%) after injection. (A) Clearance of nonopsonized RRBC. Control, no vector administered ( $\bigcirc$ ); AdNull ( $\square$ ); AdFc $\gamma$ RIIA $(\triangle)$. Each point represents the mean and standard error from 3 animals in each group. (B) Clearance of opsonized RRBC. The symbols are identical to those used in (A). Each point represents mean and standard error from 14 animals in control group, 12 animals in group infected with AdNull, and 17 animals infected with AdFc $\gamma$ RIIA. 


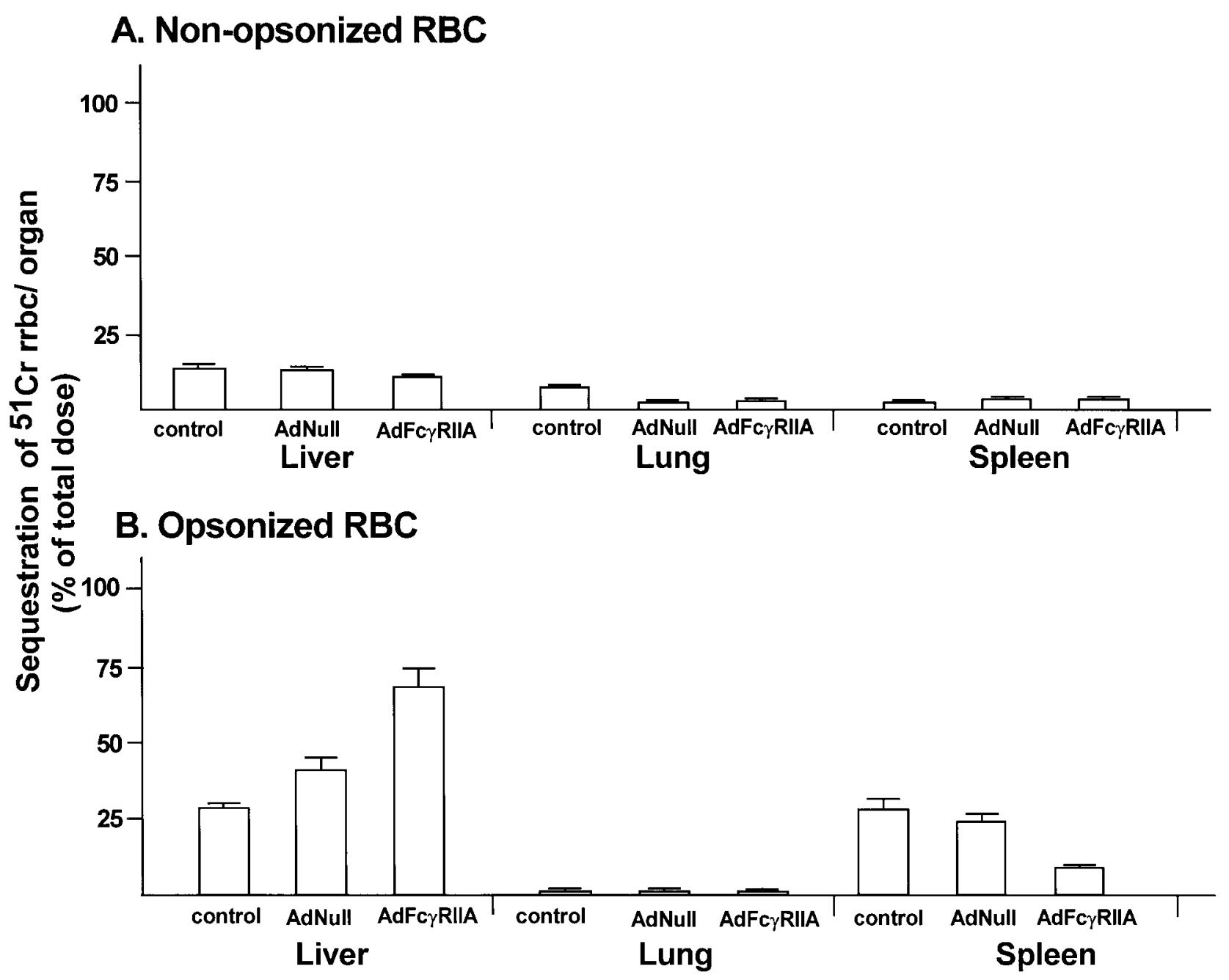

Fig 5. Organ sequestration of radiolabeled RRBC after in vivo Ad-mediated Fc $\gamma$ RIIA cDNA gene transfer. Sprague-Dawley rats were administered AdFc $\gamma$ RIIA or AdNull intravenously (109 pfu). After 48 hours, ${ }^{51} \mathrm{Cr}$-labeled opsonized (IgG-coated) RRBC or nonopsonized RRBC as controls were injected intravenously. After 120 minutes, the liver, lung, and spleen were removed and homogenized. Total radioactivity of the organs, measured in a gamma scintillation counter, is presented as a percentage of the total dose of injected radioactivity (dpm). (A) Organ sequestration after administration of nonopsonized RRBC. (B) Organ sequestration after administration of opsonized RRBC. Shown are mean percentages with standard errors from 4 animals in the control group, 6 animals in the AdNull-infected group, and 4 animals in the AdFc $\gamma$ RIIA-infected group.

controls (Fig 6A) or animals infected with AdNull (Fig 5B). The presence of fluorescent microspheres in the control and Ad Null group most likely reflects the uptake by resident liver macrophages. Taken together, these observations provide evidence that Ad-mediated transfer of FcyRIIA cDNA leads to the expression of a functional phagocytic receptor in hepatocytes and transforms these normally nonphagocytic cells into cells that are able to internalize opsonized particles and enhance their clearance from the peripheral blood.

\section{DISCUSSION}

This study demonstrates Ad-mediated transfer of Fc $\gamma$ RIIA receptor cDNA can convert nonphagocytic cells to phagocytic cells, capable of accelerating the clearance of IgG opsonized particulates in vivo. First, in vitro infection of primary rat hepatocytes with AdFcyRIIA resulted in expression of the Fc $\gamma$ RIIA on the cell surface. Second, the transfected receptor was functional, enabling normally nonphagocytic cells to recognize, bind, and phagocytose opsonized RBC. Third, intravenous administration of AdFc $\gamma$ RIIA resulted in expression of Fc $\gamma$ RIIA in hepatocytes, resulting in increased clearance of opsonized RRBC from the circulation of the experimental animals, with enhanced sequestration of RRBC in the liver.

Fc $\gamma$ RIIA receptor. Fcy receptors are receptors on the surface of phagocytic cells that recognize and bind the Fc portion of the IgG molecule. ${ }^{1-4}$ In humans, there are 3 major Fc $\gamma$ receptors: Fc $\gamma$ RI (CD64), Fc $\gamma$ RII (CD32), and Fc $\gamma$ RIII (CD16). They all exhibit a disulfide loop structure in their extracellular domain that is characteristic for all Ig gene superfamily members. Additional heterogeneity of the Fc $\gamma$ receptors results in the occurrence of different allelic forms. ${ }^{28,29}$ The FcyRIIA allotype is a $40-\mathrm{kD}$ protein with wide cellular distribution and is present on the surface of monocytes, macrophages, granulocytes, platelets, Langerhans' cells, B and T lymphocytes, and 
some mesangial cells. ${ }^{2}$ Fc $\gamma$ RIIA is the only allotype of the Fc $\gamma$ receptor that can directly mediate a phagocytic signal in the absence of an accessory chain and in the absence of other Fcy receptors. ${ }^{2,3,15}$ It is the only human Fcy receptor, which recognizes $\operatorname{IgG} 2$ efficiently, ${ }^{2,3,15}$ a component of the host defense system that plays an important role in defense against infection with encapsulated bacteria, such as, Streptococcus pneumoniae, Hemophilus influenzae, and Neisseria meningitis. ${ }^{30,31}$

Transfer of Fc $\gamma$ RIIA to nonphagocytic cells. Using transfection with recombinant plasmids, various Fc $\gamma$ receptors have been expressed on nonphagocytic cell lines (COS-1, Jurkat T cells, and fibroblasts). ${ }^{15,18,32}$ These in vitro experiments resulted in the expression of the functional Fcy receptors on the cell surface assessed by the phagocytosis of opsonized RRBC. Tyrosine phosphorylation of multiple proteins (eg, Fc $\gamma$ RIIA, ZAP-70, p72 ${ }^{\text {SYK }}$, and phospholipase $\mathrm{C} \gamma \mathrm{l}$ subunit) and an increase in intracellular $\mathrm{Ca}^{2+}$ concentration was observed after cross-linking of Fc $\gamma$ RIIA with anti-Fc $\gamma$ RIIA monoclonal antibody, ${ }^{15}$ and incubation with inhibitors of tyrosine kinase reduced phagocytic function of the transfected cells. ${ }^{33}$

In the present study, expression of Fc $\gamma$ RIIA was observed in liver parenchymal cells. Furthermore, increased clearance of IgG opsonized RBC with increased sequestration of RBC in the liver was observed in experimental animals infected with AdFc $\gamma$ RIIA, when compared with noninfected animals and animals infected with AdNull. Some degree of enhancement of the clearance of opsonized RRBC was also observed after infection with AdNull compared with noninfected animals. This is likely due to activation of resident phagocytic cells by administration of the Ad vector per se, because there was no expression of the human FcyRIIA visible in the AdNullinfected animals. Infection with the Ad vectors (AdFc $\gamma$ RIIA, AdNull) did not affect the clearance of nonopsonized RBC. The increased localization of IgG-coated fluorescent microspheres after Ad Fc $\gamma$ RIIA transfer in vivo in the liver provide additional evidence for increased uptake of $\operatorname{IgG}$ opsonized particles by liver cells of these animals.

Possible clinical significance. One application of this approach may be in in vivo enhancement of host defense in clinical situations in which phagocytosis of IgG-targeted complexes is impaired due to the downregulation of the Fcy receptors, eg, in systemic lupus erythematosus, chronic liver disease, and chronic kidney disease. ${ }^{5-7}$ In regard to defects that alter the binding of IgG-coated targets due to genetic polymorphisms (and resulting dysfunction of FcyRIIA), an arginine (R131)/histidine change at amino acid position 131 in the second Ig-like domain of the Fc $\gamma$ RIIA receptor is common. ${ }^{28,29}$ This mutation is clinically significant because FcyRIIA on leukocytes of individuals homozygous for R131/R131 ( 25\% of Caucassians) are unable to efficiently bind IgG2-opsonized bacteria. These individuals have a higher incidence of infections with encapsulated bacteria and increased mortality. ${ }^{30,31}$ The $\mathrm{R} 131 / \mathrm{R} 131$ genotype is also a risk factor for development of lupus nephritis in patients with systemic lupus erythematosus probably due to its lower affinity for certain immune complexes. ${ }^{34}$ Production of reactive oxygen intermediates by neutrophils in response to antineutrophil cytoplasmic antibodies is also significantly increased in individuals with Wegener's granulomatosis who express the R131/R131 genotype. ${ }^{35,36}$

\section{ACKNOWLEDGMENT}

The authors thank H. Carpenter and B. Ferris for technical assistance and $\mathrm{N}$. Mohamed for help preparing this manuscript.

\section{REFERENCES}

1. Ravetch JV, Kinet JP: Fc receptors. Annu Rev Immunol 9:457, 1991

2. Sandor M, Lynch RG: The biology and pathology of Fc receptors. J Clin Immunol 13:237, 1993

3. de Haas M, Vossebeld PJ, von dem Borne AE, Roos D: Fc $\gamma$ receptors of phagocytes. J Lab Clin Med 126:330, 1995

4. McKenzie SE, Schreiber AD: Fc $\gamma$ receptors in phagocytes. Curr Opin Hematol 5:16, 1998

5. Frank MM, Hamburger MI, Lawley TJ, Kimberly RP, Plotz PH: Defective reticuloendothelial system Fc-receptor function in systemic lupus erythematosus. N Engl J Med 300:518, 1979

6. Ruiz P, Gomez F, Schreiber AD: Impaired function of macrophage $\mathrm{Fc} \gamma$ receptors in end-stage renal disease. N Engl J Med 322:717, 1990

7. Gomez F, Ruiz P, Schreiber AD: Impaired function of macrophage $\mathrm{Fc} \gamma$ receptors and bacterial infection in alcoholic cirrhosis. N Engl $\mathrm{J}$ Med 331:1122, 1994

8. Gandossini M, Souhami RL, Babbage J, Addison IE, Johnson AL, Berenbaum MC: Neutrophil function during chemotherapy for Hodgkin's disease. Br J Cancer 44:863, 1981

9. Pruzanski W, Saito S, De Boer G: Modulatory activity of chemotherapeutic agents on phagocytosis and intracellular bactericidal activity of human polymorphonuclear and mononuclear phagocytes. Cancer Res 43:1420, 1983

10. Schreiber AD, Nettl FM, Sanders MC, King M, Szabolcs P, Friedman D, Gomez F: Effect of endogenous and synthetic sex steroids on the clearance of antibody-coated cells. J Immunol 141:2959, 1988

11. Yamada Y, Hara I, Gohji K, Okada H, Arakawa S, Kamidono S: Recovery of leukocyte function after super-high-dose chemotherapy with peripheral blood stem cell transplantation in testicular cancer patients. Int J Cancer 72:39, 1997

12. Hosea SW, Brown EJ, Hamburger MI, Frank MM: Opsonic requirements for intravascular clearance after splenectomy. $\mathrm{N}$ Engl $\mathrm{J}$ Med 304:245, 1981

13. Cornacoff JB, Hebert LA, Smead WL, Van Aman ME, Birmingham DJ, Waxman FJ: Primate erythrocyte-immune complex-clearing mechanism. J Clin Invest 71:236, 1983

14. Hebert LA: The clearance of immune complexes from the circulation of man and other primates. Am J Kidney Dis 17:352, 1991

15. Hunter S, Kamoun M, Schreiber AD: Transfection of an Fcy receptor cDNA induces T cells to become phagocytic. Proc Natl Acad Sci USA 91:10232, 1994

16. Rosenfeld MA, Siegfried W, Yoshimura K, Yoneyama K, Fukayama M, Stier LE, Paakko PK, Gilardi P, Stratford-Perricaudet LD, Perricaudet M, Jallat S, Pavirani A, Lecocq J-P, Crystal RG: Adenovirusmediated transfer of a recombinant alpha 1-antitrypsin gene to the lung epithelium in vivo. Science 252:431, 1991

17. Rosenfeld MA, Yoshimura K, Trapnell BC, Yoneyama K, Rosenthal ER, Dalemans W, Fukayama M, Bargon J, Stier LE, Stratford-Perricaudet L, Perricaudet M, Guggino WB, Pavirani A, Lecocq J-P, Crystal RG: In vivo transfer of the human cystic fibrosis transmembrane conductance regulator gene to the airway epithelium. Cell 68:143, 1992

18. Indik Z, Kelly C, Chien P, Levinson AI, Schreiber AD: Human Fc $\gamma$ RII, in the absence of other $F c \gamma$ receptors, mediates a phagocytic signal. J Clin Invest 88:1766, 1991

19. Hersh J, Crystal RG, Bewig B: Modulation of gene expression 
after replication-deficient, recombinant adenovirus-mediated gene transfer by the product of a second adenovirus vector. Gene Ther 2:124, 1995

20. Graham FL, Prevec L: Manipulation of adenovirus vectors, in Murray EJ (ed): Methods in Molecular Biology. Clifton, NJ, Humana, 1991, p 109

21. Crystal RG, McElvaney NG, Rosenfeld MA, Chu CS, Mastrangeli A, Hay JG, Brody SL, Jaffe HA, Eissa NT, Danel C: Administration of an adenovirus containing the human CFTR cDNA to the respiratory tract of individuals with cystic fibrosis. Nat Genet 8:42, 1994

22. Wolff G, Mastrangeli A, Heinflink M, Falck-Pedersen E, Gershengorn MC, Crystal RG: Ectopic expression of thyrotropin releasing hormone (TRH) receptors in liver modulates organ function to regulate blood glucose by TRH. Nat Genet 12:274, 1996

23. Falk LA: Measurement of Fc $\gamma$ receptor-mediated binding and phagocytosis, in Coligan JE, Kruisbeek AM, Shevach EM, Strober W (eds): Current Protocols in Immunology. New York, NY, Wiley, 1995, p 14.8.1

24. Herz J, Gerard RD: Adenovirus-mediated transfer of low density lipoprotein receptor gene acutely accelerates cholesterol in normal mice. Proc Natl Acad Sci USA 90:2812, 1993

25. Worgall S, Wolff G, Falck-Pedersen E, Crystal RG: Innate immune mechanisms dominate elimination of adenovirus vectors following in vivo administration. Hum Gene Ther 8:37, 1997

26. Sambrook J, Fritsch EF, Maniatis T: Molecular Cloning: A Laboratory Manual. Cold Spring Harbor, NY, Cold Spring Harbor Laboratory, 1989

27. Ruiz P, Gomez F, King M, Lopez R, Darby C, Schreiber AD: In vivo glucocorticoid modulation of guinea pig splenic macrophage $\mathrm{Fc} \gamma$ receptors. J Clin Invest 88:149, 1991

28. Warmerdam PA, van de Winkel JG, Gosselin EJ, Capel PJ: Molecular basis for a polymorphism of human Fc $\gamma$ receptor II (CD32). J Exp Med 172:19, 1990
29. Rascu A, Repp R, Westerdaal NA, Kalden JR, van de Winkel JG: Clinical relevance of Fc $\gamma$ receptor polymorphisms. Ann NY Acad Sci 815:282, 1997

30. Bredius RG, Derkx BH, Fijen CA, de Wit TP, de Haas M, Weening RS, van de Winkel JG, Out TA: Fc $\gamma$ receptor IIA (CD32) polymorphism in fulminant meningococcal septic shock in children. $\mathrm{J}$ Infect Dis 170:848, 1994

31. Sanders LA, van de Winkel JG, Rijkers GT, Voorhorst-Ogink MM, de Haas M, Capel PJ, Zegers BJ: Fc $\gamma$ receptor IIA (CD32) heterogeneity in patients with recurrent bacterial respiratory tract infections. J Infect Dis 170:854, 1994

32. Tuijnman WB, Capel PJ, van de Winkel JG: Human low-affinity igg receptor Fc $\gamma$ RIIA (CD32) introduced into mouse fibroblasts mediates phagocytosis of sensitized erythrocytes. Blood 79:1651, 1992

33. Indik ZK, Pan XQ, Huang MM, McKenzie SE, Levinson AI, Schreiber AD: Insertion of cytoplasmic tyrosine sequences into the nonphagocytic receptor Fc $\gamma$ RIIB establishes phagocytic function. Blood 83:2072, 1994

34. Salmon JE, Millard S, Schachter LA, Arnett FC, Ginzler EM, Gourley MF, Ramsey-Goldman R, Peterson MG, Kimberly RP: Fc $\gamma$ RIIA alleles are heritable risk factors for lupus nephritis in African Americans. J Clin Invest 97:1348, 1996

35. Porges AJ, Redecha PB, Kimberly WT, Csernok E, Gross WL, Kimberly RP: Anti-neutrophil cytoplasmic antibodies engage and activate human neutrophils via FcyRIIA. J Immunol 153:1271, 1994

36. Reumaux D, Vossebeld PJ, Roos D, Verhoeven AJ: Effect of tumor necrosis factor-induced integrin activation on $\mathrm{Fc} \gamma$ receptor II-mediated signal transduction: Relevance for activation of neutrophils by anti-proteinase 3 or anti-myeloperoxidase antibodies. Blood 86: 3189, 1995 


\section{Enhanced Liver Uptake of Opsonized Red Blood Cells After In Vivo Transfer of Fc $\gamma$ RIIA cDNA to the Liver}

Petr Bezdicek, Stefan Worgall, Imre Kovesdi, Moo-Kyung Kim, Jong-Gu Park, Theresa Vincent, Philip L. Leopold, Alan D. Schreiber and Ronald G. Crystal

Updated information and services can be found at:

http://www.bloodjournal.org/content/94/10/3448.full.html

Articles on similar topics can be found in the following Blood collections Immunobiology (5361 articles)

Information about reproducing this article in parts or in its entirety may be found online at:

http://www.bloodjournal.org/site/misc/rights.xhtml\#repub_requests

Information about ordering reprints may be found online at:

http://www.bloodjournal.org/site/misc/rights.xhtml\#reprints

Information about subscriptions and ASH membership may be found online at:

http://www.bloodjournal.org/site/subscriptions/index.xhtml

Blood (print ISSN 0006-4971, online ISSN 1528-0020), is published weekly by the American Society of Hematology, 2021 L St, NW, Suite 900, Washington DC 20036.

Copyright 2011 by The American Society of Hematology; all rights reserved. 